American Journal of Pharmacology and Toxicology 4 (3):80-84, 2009

ISSN 1557-4962

(C) 2008 Science Publications

\title{
Cytoprotective Effect of UIGen, a Polyherbal Formulation against Physical and Chemical Factor Induced Gastric Ulcers in Wister Albino Rats
}

\author{
${ }^{1}$ T.S. Muralidhar, ${ }^{2}$ Anna Balaji, ${ }^{1}$ Chinmay Bandopadhyay and ${ }^{3}$ S.L. Shantha \\ ${ }^{1}$ Department of Biotechnology, R and D Center, Dayananda Sagar College of Biological Sciences, \\ Kumarswamy Layout, Bangalore-560078, India \\ ${ }^{2}$ Dayananda Sagar College of Pharmacy, Kumarswamy Layout, Bangalore-560078, India \\ ${ }^{3}$ Department of Biotechnology, \\ People Education Society College, 100 Feet Ring Road, Bangalore, India
}

\begin{abstract}
Problem statement: UlGen, a Polyherbal formulation, was investigated for its possible Ulcero-protective activity in ulcerogen and Cold-restraint stress induced Wister rats (Rattus rattus). Oral administration of UlGen, at a dose of $800 \mathrm{mg} \mathrm{kg}^{-1}$ significantly protected the onset of coldresistance stress induced ulcerations. Approach: It significantly inhibited gastric ulceration induced by alcohol and aspirin. Control group: Alcohol 80\% induced ulcer was 42.00 \pm 2.30 and in UlGen treated rats showed $10.00 \pm 1.62$. Using alcian blue stain to study the mucus secretion by mucosal cells carried out histological examination of gastric glandular mucosa. Results: The volume and acidity of gastric juice in pyloric-ligated rats was reduced in treated rats. Gastric volume $\left(\mathrm{mL} 100 \mathrm{~g}^{-1}\right)$ in control rats showed 4.12 \pm 0.32 and in UlGen treated rats showed 2.50 \pm 0.20 . Conclusion: UlGen, Cytoprotective effect may be due to the enhancement of defensive mechanism through an improvement of gastric cytoprotection as well as acid inhibition.
\end{abstract}

Key words: UlGen, gastric ulceration, cold-resistance stress, pyloric-legated, gastric cytoprotection, ulcer index

\section{INTRODUCTION}

Onset of peptic ulcers has been described as an imbalance between the luminal acid peptic attacks versus the mucosal defense. Acid and pepsin components form the aggressive factor and the mucus layer of mucin-bicarbonate secretions; phospolipid layer, tight junctions, cell proliferations, prostaglandins and the urogastrone/Epidermal Healing Factors (URO/EHF) form the defensive factors ${ }^{[17]}$.

Since its recognition of the peptic ulcer has an important chemical entity, various efforts have been made to assess reliable remedial measures. In peptic ulcer disease, the basis of using antacids as an $\mathrm{H}_{2}$ receptor antagonists and proton pump inhibitors like omeprazole $^{[8]}$.

However, not all patients with gastric ulcers have increased acid secretion. It has been reported by various researchers that acid secretion remains within the normal range. The decreased mucosal resistance could be the dominant factor. Recently, the role of mucosal factor in peptic ulceration has received much attention and the term 'cytoprotection' has been incorporated ${ }^{[1]}$.
It is now well established that strengthening the defensive mechanisms of gastric mucosa rather than attenuating the factors of aggression causing ulceration can prevent peptic ulcer disease ${ }^{[9]}$.

This led to the introduction of carbonoxolone sodium, sucralfate and Prostaglandin (PGs) in the therapeutic interventions for the treatment of peptic ulcer disease. However, some of them, including carbenoxolene sodium and PGs, have harmful side effects $^{[2,3]}$.

Because of these reasons, efforts were made to find a suitable nontoxic and curative agent for the treatment of peptic ulcer disease in natural products from plant origin $^{[14]}$.

A large section of the World's population relies on traditional and Medicinal herbs they are an indispensable part of the traditional medicine ${ }^{[23]}$ practiced all over the world due to less cost, easy access and Vedic expertization.

In this study, as per the complied data on traditional herbs from ancient Ayurvedic scripts, antiulcerogenic activity was selected. The herbal formulation consists of four medicinal plants, namely

Corresponding Author: T.S. Muralidhar, Department of Biotechnology, R and D Center,

Dayananda Sagar College of Biological Sciences, Kumarswamy Layout, Bangalore-560078, India 
Glycyrrhiza glabra (Papilionaceae; Root), Saussurea lappa (Compositae; Root), Aegle marmelos (Rutaceae; Fruit) and Santalum album (Santalaceae; Stem).

\section{MATERIALS AND METHODS}

Selected healthy animals of Wistar albino rats strain of either sex (180-220 g) were housed at room temperature of $22 \pm 2{ }^{\circ} \mathrm{C}$ under a $12: 12$ light dark cycle and were fed a synthetic diet (Lipton India Ltd.). Water was allowed ad libitum.

The plants constituents were procured from authentic sources and were identified and the voucher specimen was deposited in the herbarium of our Dept of Biotechnology. All plant powders were individually weighed in equal proportions and mixed. Drugs were administered as oral aqueous suspension and the animals of the control group received water as vehicle. Experimental gastric ulcers were produced in rats as follows:

Drug induced gastric ulcers in rats: Aspirin $\left(0.2 \mathrm{~g} \mathrm{~kg}^{-1}\right.$ for 3 days) and alcohol ( $1 \mathrm{ml}$ of $80 \%$ rats as a single dose) were administered once per day to groups of animals for the number of days specified ${ }^{[6,10]}$. Animals of control group received water $\left(10 \mathrm{~mL} \mathrm{~kg}{ }^{-1}\right)$ and test groups received UlGen $\left(0.8 \mathrm{~g} \mathrm{~kg}^{-1}\right)$ for 10 days orally. From day 8 the animals received water/UlGen, $2 \mathrm{~h}$ prior to the administration of aspirin.

Alcohol was administered on day 10, $2 \mathrm{~h}$ after administration of water/UlGen. Overnight fasted animals were sacrificed by cervical dislocation $1 \mathrm{hr}$ after the last dose of ulcerogen. The stomach was incised along the greater curvature and examined for ulcers.

Cold-restraint stress induced ulcers: UlGen $\left(0.8 \mathrm{~g} \mathrm{~kg}^{-1}\right)$, were administered orally for 7 days. On day 7 overnight fasted rats were restrained on a wooden plank 30 min after administration of test drugs and kept for $2 \mathrm{~h}$ in a refrigerator at $4-6^{\circ} \mathrm{C}^{[1]}$. After the period of immobilization, the rats were sacrificed by cervical dislocation and the stomachs were removed for ulcer scoring.

Pylorus ligated rats: UlGen $\left(0.8 \mathrm{~g} \quad \mathrm{~kg}^{-1}\right)$ was administered for a period of 7 days. On the day 7, after the last dose of UlGen, the rats were kept for $24 \mathrm{~h}$ fasting and care was taken to avoid coprophagy. Under light ether anesthesia, the abdomen was opened and pylorus was ligated without causing any damage to its blood supply. The stomach was replaced carefully and the abdominal wall was closed with interrupted sutures.
The animals were deprived of water during the postoperative period $^{[20]}$. Four hours after ligation, Stomachs were dissected out and contents were collected into tubes. Volume, $\mathrm{pH}$, free acid and total acid content ${ }^{[15]}$ of gastric juice were determined. The stomach was opened along the greater curvature and examined for ulcers.

Estimation of gastric mucus barrier in rats: The rats were with UlGen $\left(0.8 \mathrm{~g} \mathrm{~kg}^{-1}\right)$ once per day orally for 7 days. On day 8 the over-night fasted rats were sacrificed and stomachs were removed. The glandular portion of the stomach was excised and opened along the lesser curvature. The everted stomachs were soaked for $2 \mathrm{~h}$ in $0.1 \%$ alcian blue dissolved in $0.16 \mathrm{M}$ sodium acetate, adjusted to $\mathrm{pH} 5.8$ with hydrochloric acid. Uncomplexed dye was removed by two successive washes at 15 and $45 \mathrm{~min}$ in $0.25 \mathrm{M}$ sucrose. Dye complexed with mucus was diluted by immersion in 10 $\mathrm{mL}$ aliquots of $0.5 \mathrm{M}$ magnesium-chloride or $2 \mathrm{~h}$. The resulting blue solutions were shaken briefly with equal volumes of diethyl ether and the optical density of aqueous phase was measured at $605 \mathrm{~nm}^{[5]}$. Using alcian blue stain to study the mucus secretion by mucosal cells carried out histological examination of gastric glandular mucosa.

The method of ${ }^{[19]}$ was used to evaluate the ulcer index. Statistical analyses were carried out by using Student's t-test for gastric ulcers.

\section{RESULTS}

This project study was undertaken to study the anti-ulcerogenic effect of, a poly herbal preparation containing herbs that are mentioned in Ayurvedic scripts as a remedy for, 'Amlapitta', which closely resembles peptic ulcers ${ }^{[21]}$.

UlGen was found to prove an antiulcerogenic property in experimental gastric ulcers in rats. UlGen significantly decreased the aspirin-induced ulcers index from $25.00 \pm 1.20$ in the control group to $15.00 \pm 2.02$ in the treated group (Table 1). There was a significant reduction in alcohol induced ulcer index from $42 \pm 2.30$ in the control group to $10.00 \pm 1.62$ in the treated group (Table 1).

Table 1: Effect of Ulgen on aspirin, alcohol and cold-restraint stress induced gastric ulcers in rats

\begin{tabular}{lll}
\hline & Control & Treated Ulgen \\
\hline Aspirin $200 \mathrm{mg} \mathrm{Kg}^{-1}$ & $25.00 \pm 1.20$ & $15.00 \pm 2.02^{\#}$ \\
Alcohol $80 \%$ & $42.00 \pm 2.30$ & $10.00 \pm 1.62^{\circ}$ \\
Cold Restraint stress & $31.50 \pm 2.00$ & $20.60 \pm 3.02^{\circ}$ \\
\hline
\end{tabular}

Values are mean $\pm \operatorname{SE}(n=6) .^{\#}: \mathrm{p}<0.01 ;{ }^{\circ}: \mathrm{p}<0.025 ; \bullet: \mathrm{p}<0.001$.

Compared with respective control group 
Am. J. Pharm. \& Toxicol., 4 (3):80-84, 2009

Table 2: Effect of Ulgen on gastric volume, free acid, total acid and ulcer index and ulcer index in pylorus ligated rats $(\mathrm{n}=10)$

\begin{tabular}{|c|c|c|c|c|}
\hline Group & Gastric volume $\left(\mathrm{mL} 100 \mathrm{mg}^{-1}\right)$ & Free acid (M Eq $\left.100 \mathrm{~g}^{-1} 4 \mathrm{~h}^{-1}\right)$ & Total acid (M Eq $\left.100 \mathrm{~g}^{-1} 4 \mathrm{~h}^{-1}\right)$ & Ulcer index \\
\hline Control & $4.12 \pm 0.32 *$ & $385 \pm 32.10^{*}$ & $492.30 \pm 27.50^{*}$ & $30.02 \pm 0.5^{*}$ \\
\hline Ulgen treated & $2.50 \pm 0.20 *$ & $215 \pm 21.60^{*}$ & $321.25 \pm 30.07^{*}$ & $16.50 \pm 3.2 *$ \\
\hline
\end{tabular}

UlGen significantly reduced the volume of gastric juice, total acid, free acid and ulcer index as compared to the control group (Table 2).

\section{DISCUSSION}

A significant improvement in total gastric barrier mucus was observed after UlGen treatment. The gastric mucin content in the control group was $38.5 \pm 2.1$ as compared to $58.1 \pm 5.2$ in the UlGen treated group. Alcian blue characteristically stains the sialomucin ${ }^{[4]}$. Intense staining of gastric mucosa by alcian blue at the apical region and in the deeper mucosal layer as compared to control indicates that UlGen treatment promotes mucus secretion by the mucosal cells (microphotograph: Stomachs).

Peptic ulcer is now widely believed to be due to the imbalance between offensive acid-pepsin and defensive mucus factors. UlGen was found to increase the mucus and decrease the acid volume, free and total acid contents in the rats. These effects of UlGen in these ulcer models that influence the initiation and cytoprotection of ulceration may be considered as highly desirable properties of an anti-ulcerogenic drug. Duodenal ulcers produced by the injection of histamine ${ }^{11}$ into guinea pigs, are the result of contact of duodenum with the acid gastric juice so their incidence may change with the rate of emptying of stomach. On the other hand production of gastric ulcer would require the revitalizations of gastric mucosa by a high doe of histamine prior to the action of gastric juice. Even before 1962 some authors insisted on different origins of experimental ulcers of the stomach and duodenum ${ }^{[7]}$.

In another study the evaluation of Aspirin+Pylorus Ligation (APL) and Alcohol (AL) induced acute gastric ulcer models and ulcer-healing activity using acetic acid-induced (AC) chronic ulcer model in rats. Both the antisecretory and cytoprotection hypothesis were evaluated. The antioxidant activity of Jasminum grandiflorum L. (JGLE) has been assayed by using in vitro methods like 2,2-diphenyl-1-picrylhydrazylhydrate (DPPH) assay ${ }^{[22]}$.

Phytochemical investigation of Byrsonima crassa leaves consists of 5 phenolic compounds may probably revealed antiulcerogenic effects; The $\mathrm{MeOH}$ extract reduced the ulceration by 93 and $99 \%$ only at the doses of 500 and $1000 \mathrm{mg} \mathrm{kg}^{-1}$. The lower gastroprotective action (69\%) was observed when animals were treated with $\mathrm{CHCl}_{3}$ extract at the dose of $1000 \mathrm{mg} \mathrm{kg}^{-1[16]}$.

Precise information on receptors and signal transduction mechanisms as well as on intramural neural and paracrine regulatory pathways has led to the development of new drugs capable of inhibiting acid secretion. These include antagonists that interact with stimulatory receptors (histamine H2-receptor antagonists, muscarinic receptor antagonists and gastrin receptor antagonists), agonists that interact with inhibitory receptors (somatostatin and prostaglandin E analogues) and irreversible inhibitors of the luminal enzyme, $\mathrm{H}+\mathrm{K}(+)$-ATPase ${ }^{[18]}$.

One study demonstrated that CorticotrophinReleasing Factor (CRF) injected in a picomole amount into the cerebrospinal fluid acts within the brain to inhibit gastric emptying of a liquid meal through vagaldependentpathways ${ }^{[21]}$.

The reduction in gastric fluid volume, total acidity and an increase in the $\mathrm{pH}$ of the gastric fluid in APL rats proved the anti secretary activity of JGLE. Additionally, JGLE completely healed the ulcer within 20 days of treatment in $\mathrm{AC}$ model as evidenced by histopathological studies ${ }^{[22]}$.

In our study alcian blue stain is used to evaluate the extent of mucus secretion by mucosal cells carried out in histological and histochemical examination of gastric glandular mucosa revealed that as when compared to stress induced stomach (Control): lot of mucosal surface layer distortions and ulceration are visible, (Fig. 1). In Ulgen treated stomach rats, extensive mucus secretion were evident this could be due to drug response (Fig. 2).

Bioassay-guided fractionation led to the isolation of two bioactive indole alkaloids called canthin-6-one (1) and 4-methoxycanthin-6-one (2). The alkaloid fraction and both alkaloids demonstrated potent antiulcerogenic effects when evaluated in gastric lesioninduced animals, Simaba ferruginea St. Hill (Simaroubaceae) $^{[24]}$.

Phytochemical investigation on hydroethanolic extract of the leaves (HEL) and bark (HEB) from the plant Alchornea castaneaefolia and enriched flavonoidic fraction led to the isolation of flavonoids glycosides as the main compounds, thus suggesting that these substances may be involved in the observed antiulcer activity ${ }^{[12]}$. 


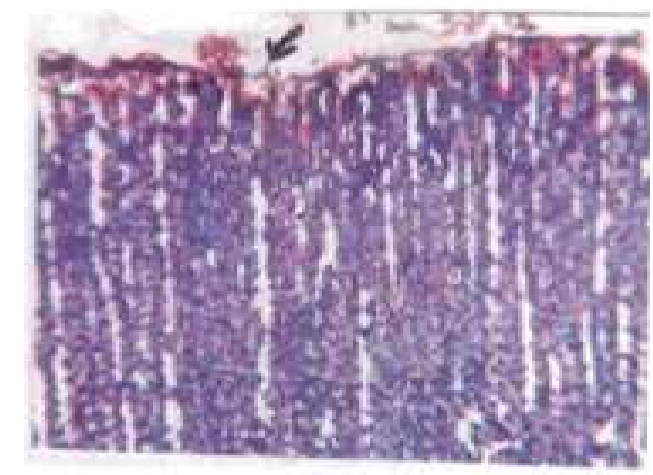

Fig. 1: Control: Stomach-stress induced ulcer $(\longleftarrow)$

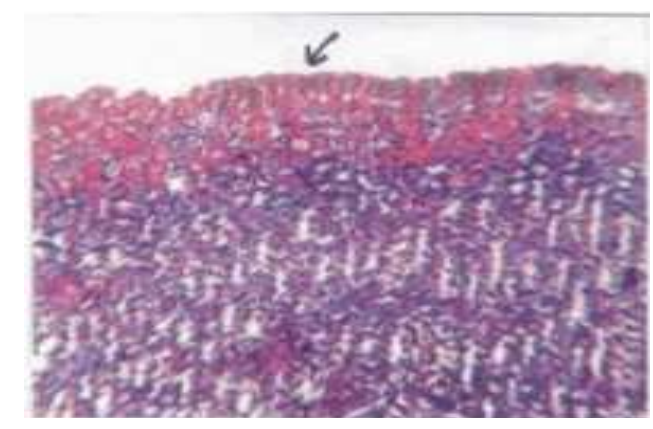

Fig. 2: Treated Ulgen: Ulcer protection $(\leftarrow)$; (Stomach): Drug response

Solanum nigrum (SNE) fruits extract significantly inhibits $\mathrm{H}(+) \mathrm{K}(+)$ ATPase activity and decreases the gastrin secretion in EtOH-induced ulcer model.

The severity of the reaction of ulcerogen and the reduction of ulcer size by SNE was evident by histological findings. SNE, thus, offers antiulcer activity by blocking acid secretion through inhibition of $\mathrm{H}(+)$.

K (+) ATPase and decrease of gastrin secretion. These results further suggest that SNE was found to possess antiulcerogenic as well as ulcer healing properties, which might also be due to its antisecretory activity ${ }^{[13]}$.

The extracts of Byrsonima crassa leaves, phenolic compounds may probably acting as an antiulcerogenic effect $^{[6]}$.

After Helicobacter pylori eradication was introduced and largely eliminated the need for maintenance therapy for peptic ulcer disease, Gastroesophageal Reflux Disease (GERD) became the main indication for prolonged gastric acid inhibition. The drug effect on GERD depends on the degree of acid inhibition, thus the efficacious proton pump inhibitors are preferred. The proton pump inhibitors have few immediate side effects, the main concern being the profound hypoacidity and hypergastrinaemia they induce. Gastric hypoacidity also increases gut bacterial infections and the barrier function of acid against viral and prion infections requires further assessment $^{[25]}$.

\section{CONCLUSION}

The experimental data concluded that, UlGen activity may be due to the enhancement of defensive mechanism through an improvement of gastric cytoprotection as well as acid inhibition.

\section{ACKNOWLEDGEMENT}

The researchers are extremely grateful to Dr. Premchandra Sagar, Vice Chairman, DSI and Dr. P.S. Rao. Director. Biological sciences. DSI. Bangalore560078. India, for their immense guidance and support for this project.

\section{REFERENCES}

1. Aguwa, C.N. and G.C. Mittal, 1987. Study of antiulcer activity of an aqueous extract of leaves of Pvrenaeaiitha Mandtii (family-leacinaceae) using various model of experimental gastric ulcer in rat. Eur. J. Pharmacol., 74: 215-219. DOI: 10.1002/1099-1573(200012)14:8

2. Barrowman. J.A. and C.J. Pfeiffer, 1982. Carbenoxlone: A Critical Analysis of Its Clinical Value in Peptic Ulcer. In: Drugs and Peptic Ulcer, Pfeiffer, C.J. (Ed). CRC Press, Boca RATON, pp: 123-132. DOI: 10.1016/0378-8741(95)01414-4

3. Borella, L.E., K. Seethaler and W. Lipmann, 1979. Sucralfate: Antipeptic, antiulcer activities and antagonism of gastric emptying. Arzneimforsch, 29: 793-798. DOI: 10.1016/S0248-8663(85)80124-7

4. Brown, G.G., 1978. An Introduction to Histotechnology. 1st Edn., Appleton Century Crofts, New York, pp: 293-308.

5. Corney, S.J., S.N. Morrissay and R.J. Woods, 1974. A method for the quantitative estimation of gastric burner mucous. Proc. Physiol. Soc., 242: 116-117. http://jp.physoc.org/cgi/content/citation/242/2/116

6. Derelanko, M.J. and J.F. Long, 1981. Carbenoxolone sodium protects gastric mucosa against ethanol induce necrosis. Proc. Soc. Exp. Biol. Med., 166: 394-397. PMID: 7208496

7. Holz. S., 1968. Drug action on digestive system. Ann. Rev. Pharmacol., 8: 171-186. DOI: 10.1146/annurev.pa.08.040168.001131 
8. Feldman, M., 1989. Gastric Secration in Health and Disease. In: Gastroenterology Disease: Pathophysiology, Diagonosis and Management, Sleisengr, M.R. and J.S. Fordtan (Eds.). WB Saunders, Philadelphia, pp: 713-734.

9. Freston, J.W., 1990. Overview of medical therapy of peptidic ulcer disease. Gastroenterol. Clin. North Am., 19: 121-140. http://www.ncbi.nlm.nih.gov/pubmed/2184124

10. Goel, R.K., S. Gupta, R. Shankar and A.K. Sanyal, 1986. Anti ulcerogenic effect of banana powder (Musa sapientum var paradisisca) and its effect on the mucosal resistant. J. Ethnopharmacol., 18: 33-44. http://www.ncbi.nlm.nih.gov/pubmed/3821133

11. Gupta, J.P., Y. Rai, P.K. Debnath and A.K. Sanyal, 1980. A comparative study of on the gastric secretion of histamine and penta gastrine on the same Indian subjects. Asian Med. J., 23: 553-565. DOI: 10.1016/0378-8741(95)01414-4

12. Hiruma-Lima, C.A. et al., 2002. Natural transcrotonin: The antiulcerogenic effect of another diterpene isolated from the bark of Croton cajucara BENTH. Biol. Pharm. Bull., 25: 452. http://www.ncbi.nlm.nih.gov/pubmed/11995923

13. Jainu, M. and C.S. Devi, 2006. Antiulcerogenic and ulcer healing effects of Solanum nigrum (L.) on experimental ulcer models: possible mechanism for the inhibition of acid formation. $\mathrm{J}$. Ethnopharmacol., 104: 156-163. http://www.ncbi.nlm.nih.gov/sites/entrez

14. Marini Bettlo, G.B., 1980. Present aspects of the use of medicinal plants in traditional medicine. $\mathrm{J}$. Ethnopharmacol., 2: 5-7. http://www.ncbi.nlm.nih.gov/pubmed/7464184

15. Parmor, N.S., G. Hennings and O.P. Gulti, 1984. The gastric antisecratory activity of 3-methoxy5,7,3,4, tetrahydroxy flavan (ME)-a specific histidine decarbooxylase inhibitor in rats. Agents Actions, 15: 143-145.

16. Sannomiya, M. Vitor B. Fonseca, M.A. da Silva, L.R.M. Rocha and L.C. dos Santos et al., 2005. Flavonoids and antiulcerogenic activity from Byrsonima crassa leaves extracts. J. Ethnopharmacol., 97: 1-6. http://www.ncbi.nlm.nih.gov/pubmed/15652267

17. Sanyal, A.K.K., P.K. Metra and R.K. Goal, 1983. Modified methods to estimate desolve muco substance in gastric juice. Indian J. Exp. Biol., 21: 78-80. DOI: 10.1016/J.INTIMP.2009.02.014
18. Schubert, M.L. and R.D. Shamburek, 1990 Mar, control of acid secretion. Gastroenterol. Clin. North Am., 19: 1-25. DOI: 10.1016/S0889553(05)70189-8

19. Souza-Formigoni, M.L., M.G. Oliveira, M.G. Monteiro, N.G. da Silveira-Filho, S. Braz and E.A. Carlini, 1991. Aug, antiulcerogenic effects of two maytenus species in laboratory animals. J. Ethnopharmacol., 34: 21-27. http://ajpgi.physiology.org/cgi/content/abstract/

20. Shay et al., 1945, Method of pylorus ligation without causing any damage to its blood supply. Gastroenterology, 5: 43-61. DOI: 10.1016/J.JEP.2006.10.0.17

21. Tache, Y., M. Maeda-Hagiwara and C.M. Turkelson, 1987. Central nervous system action of corticotropin-releasing factor to inhibit gastric emptying in rats. Am. J. Physiol. Gastrointest. Liver Physiol., 253: G241-G245. http://www.ncbi.nlm.nih.gov/pubmed/3497585

22. Umamaheswari, M., K. Asokkumar, R. Rathidevi, A.T. Sivashanmugam, V. Subhadradevi and T.K. Ravi, 2007. Antiulcer and in vitro antioxidant activities of Jasminum grandiflorum L. J. Ethnopharmacol., 110: 464-470. http://www.ncbi.nlm.nih.gov/pubmed/17125945

23. Varga, D., B.S. Misra and R.L. Vaisya, 1969. Bhavaprakash Nighantu of Shri Bhava Mista (1500-1600 AD). 5th Edn., Chaukhambha Sanskrit Sansthal, Varanasi, pp: 605-606.

24. Naturforsch, Z., V.F. Noldin, D.T. de Oliveira Martins, C.M. Marcello, J.C. da Silva Lima, F. Delle Monache and V. Cechinel Filho, 2005. Phytochemical and antiulcerogenic properties of rhizomes from Simaba ferruginea St. Hill. (Simaroubaceae). J. Biosci., 60: 701-706. http://www.biomedexperts.com/Abstract.bme/1632 0611/Phytochemical_and_antiulcerogenic_properti es_of_rhizomes_from_Simaba_ferruginea_St_Hill Simaroubaceae

25. Waldum, H.L., E. Brenna and A.K. Sandvik, 2002. Long-term safety of proton pump inhibitors: risks of gastric neoplasia and infections. Expert Opin. Drug Saf., 1: 29-38. http://www.ncbi.nlm.nih.gov/pubmed/12904157 